\title{
Metastatic Squamous-Cell Carcinoma of the Lung Arising in a 12-Year-Old Boy with Juvenile Recurrent Respiratory Papillomatosis of Neonatal Onset
}

\section{Akciğerin Metastatik Skuamoz Hücreli Karsinomu; Neonatal Dönemde Ortaya Çıkan Tekrarlayan Respiratuvar Papillomatozis Olgusu; 12 Yaşında Erkek Hasta}

\author{
Sabah BOUDJEMAA ${ }^{1}$, Nicolas LEBOULANGER ${ }^{1}$, Linda DAINESE' ${ }^{1}$, Patricia DE CREMOUX'1, \\ Hubert DUCOU LE POINTE², Aurore COULOMB ${ }^{1}$
}

Department of ${ }^{1}$ Pathology and ${ }^{2}$ Radiology, Hopital Armand Trousseau, PARIS, FRANCE

\begin{abstract}
Juvenile recurrent respiratory papillomatosis is the most common benign neoplastic disease of the larynx in children, characterized by numerous squamous papillomas caused by Human Papilloma Virus type 6 and 11. HPV is thought to be acquired at the time of vaginal delivery from maternal genital condylomas. Juvenile recurrent respiratory papillomatosis can be protracted by surgical interventions performed to avoid airway obstruction and extend below the vocal cords as far as the main stem bronchi. Lung involvement in Juvenile recurrent respiratory papillomatosis seems to be more prevalent than non-systematic reviews have reported until now and progression to cancer occurs in a significant proportion of these cases at a younger age than previously reported. This would suggest that closer attention should be paid to these children. We report a case of malignant transformation in a 12 year-old boy followed-up since the birth for an invasive juvenile recurrent respiratory papillomatosis with pulmonary involvement. The presence of HPV 6/11 was demonstrated by PCR analysis performed on material obtained from a metastatic vertebral lesion.
\end{abstract}

Key Words: Human papillomavirus, Squamous cell carcinoma, Recurrent respiratory papillomatosis, Children

\section{INTRODUCTION}

Juvenile recurrent respiratory papillomatosis (JRRP) is the most frequent benign neoplasic disease of the larynx in children and adolescents (1). JRRP is characterized by numerous benign squamous papillomas of the respiratory tract, usually confined to the larynx and self-limited. Occasionally, the behaviour is more aggressive, with persistent, recurrent papillomas and spread to the inferior airways (2). This distal involvement has been reported to

(Turk Patoloji Derg 2014, 30:133-136)

Received : 03.10.2013 Accepted : 29.01.2014

\section{ÖZ}

Juvenil tekrarlayan respiratuvar papillomatozis, Human Papilloma virüs tip 6 ve 11'in neden olduğu çok sayıda skuamöz papillomlarla karakterli, çocuklarda larenksin en sık görülen benign neoplastik hastalığıdır. HPV enfeksiyonunun vaginal doğum sırasında maternal genital kondilomdan kazanıldığı düşünülmektedir. Juvenil tekrarlayan respiratuvar papillomatozis'te havayolu tıkanıklığını ve vokal kordun altıdan ana bronkusa uzanımını önlemek için cerrahi girişimler uygulanmaktadır. Juvenil tekrarlayan respiratuvar papillomatozis'de akciğer tutulumu şimdiye kadar raporlanandan daha sıktır ve olguların çoğunda önceki raporlara göre daha erken yaşta kanser gelişimi görülmektedir. $\mathrm{Bu}$ nedenle, çocuklar yakın takibe alınmalıdır. Hastamız doğduğundan itibaren invaziv juvenil tekrarlayan respiratuvar papillomatozis tanısıyla takipli, akciğer tutulumu olup malign transformasyon gelişen 12 yaşında erkek çocuktur. HPV 6/11 varlığı vertebra metastazından alınan örnekte çalışılan PCR ile gösterilmiştir.

Anahtar Sözcükler: İnsan papillomavirusu, Skuamöz hücreli karsinom, Tekrarlayan respiratuvar papillomatozis, Çocuklar

occur in the trachea in $2-26 \%$ of cases and in the lungs in $2.3 \%$ of cases $(3,4)$.

The strongest risk factor for JRRP is a maternal history of genital papillomas transmitted during delivery. JRRP is due to infection with Human Papilloma Virus (HPV) mainly of type 6 and $11(2,5,6,7)$. Although these HPV types are thought to be of «low risk» in the genitary tract, patients with JRRP can develop broncho-pulmonary carcinoma, especially those who receive radiation or cytotoxic drugs or subsequently smoke (8).

Correspondence: Sabah BOUDJEMAA

Hopital Armand Trousseau, Department of Pathology, PARIS, FRANCE

E-mail: sabah.boudjemaa@trs.aphp.fr Phone: +3 3144736018 
We report a new case of metastatic squamous cell carcinoma associated with HPV6/11 in a 12 year-old boy managed for a neonatal onset JRRP with pulmonary involvement.

\section{CASE REPORT}

Clinical data, since the birth of the child were available and reviewed. A Guyanese child presented with respiratory symptoms, shortly after birth. He was born at full-term and delivered vaginally. It is not known whether his mother had genital condylomas. These respiratory symptoms leaded to the discovery of papillomatosis affecting the whole upper airways (nose, trachea and bronchi). At the age of 4 months, he underwent a tracheotomy due to upper airway obstruction. A biopsy performed in Guyana confirmed benign papillomatosis. The patient referred to our institution at the age of 6 months and underwent a surgical management consisting in airway desobstruction with laser procedures and XPS shaver, without any improvement.

Medical therapy consisting in 15 cycles of intravenous administration of cidofovir was started in January 2001, followed by local injections into the larynx every month since April 2002 (7,5 mg/ml, from 10 to $20 \mathrm{ml}$ each time). Between July and September 2007, he weekly received aerosols of cidofovir (30 mg each). No clinical response was obtained despite surgical and medical management, requiring 234 hospitalizations and 150 endoscopies under general anesthesia between 1997 and 2008. The tracheotomy could not be removed at any time.

At the age of 12 year-old, a follow-up computed tomography (CT) scan demonstrated a large pulmonary mass with mediastinal lymphadenopathies (Figure 1) and a lumbar spine (L2) lytic lesion (Figure 2). The pulmonary tumor was

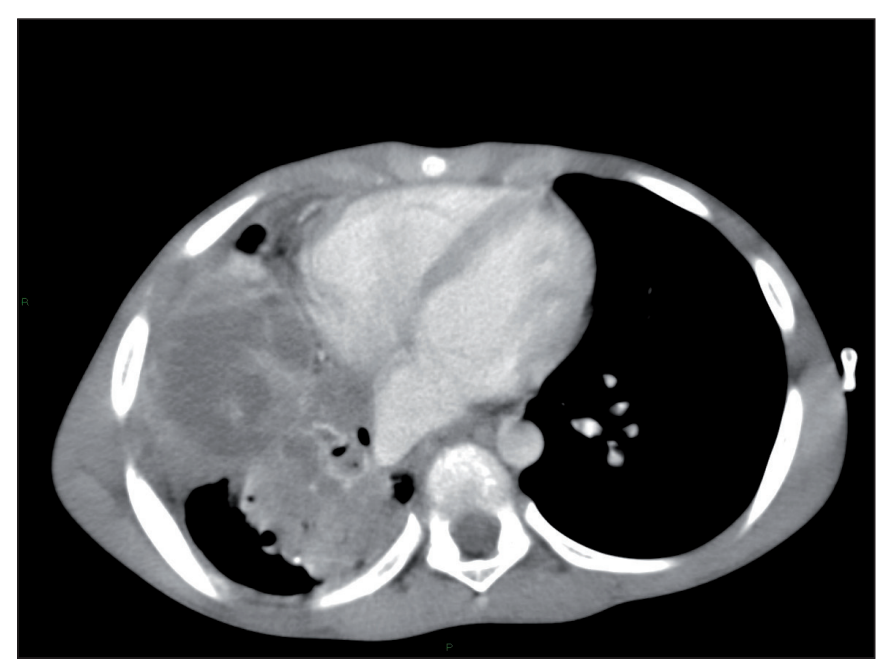

Figure 1: Thoracic TDM showing pulmonary mass with mediastinal lymphadenopathies. not accessible to biopsy or surgical resection and persisted after a broad-spectrum intravenous antibiotherapy. A fine needle aspiration (FNA) and a CT-guided fine needlebiopsy were then performed on the L2 lytic lesion. The cytologic material obtained was analyzed after MGG stain. Tissue for microscopic examination was fixed in formalin and processed routinely. Sections $(5 \mu \mathrm{m})$ were cut from the paraffin blocks and stained with haematoxylin-eosinsaffron. FNA showed numerous differentiated squamous cells. Biopsies measured $10 \mathrm{~mm}$ in greatest length. Microscopic examination showed infiltration of bone by a carcinoma composed of sheets of polygonal tumor cells with abundant eosinophilic cytoplasm and vesicular nuclei, mild atypia and a low mitotic rate. Keratinization was focally present. A bone metastasis from pulmonary

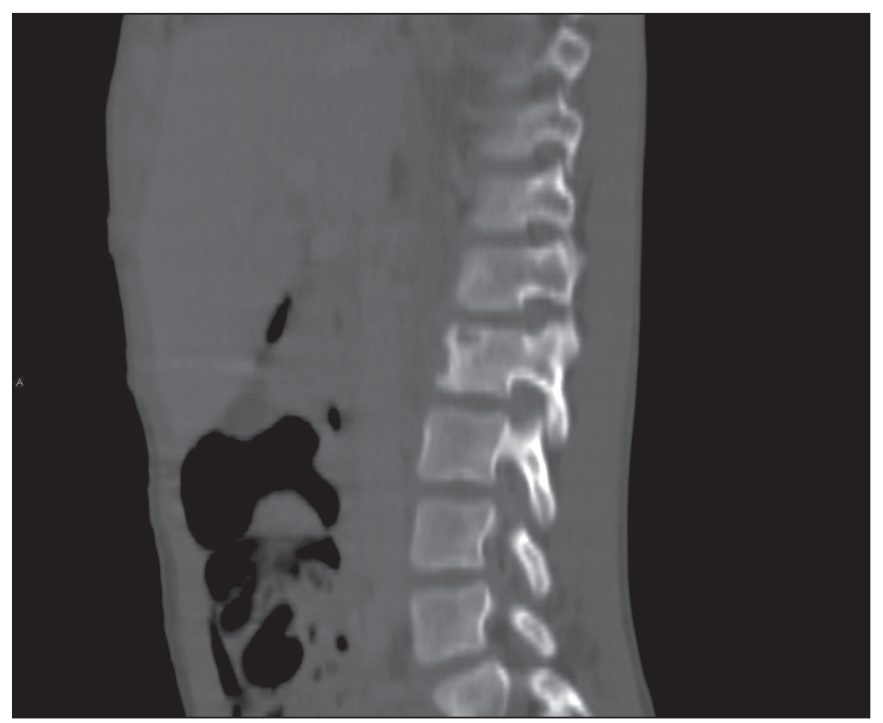

Figure 2: Spinal TDM: peripheral lytic lesion in L2.

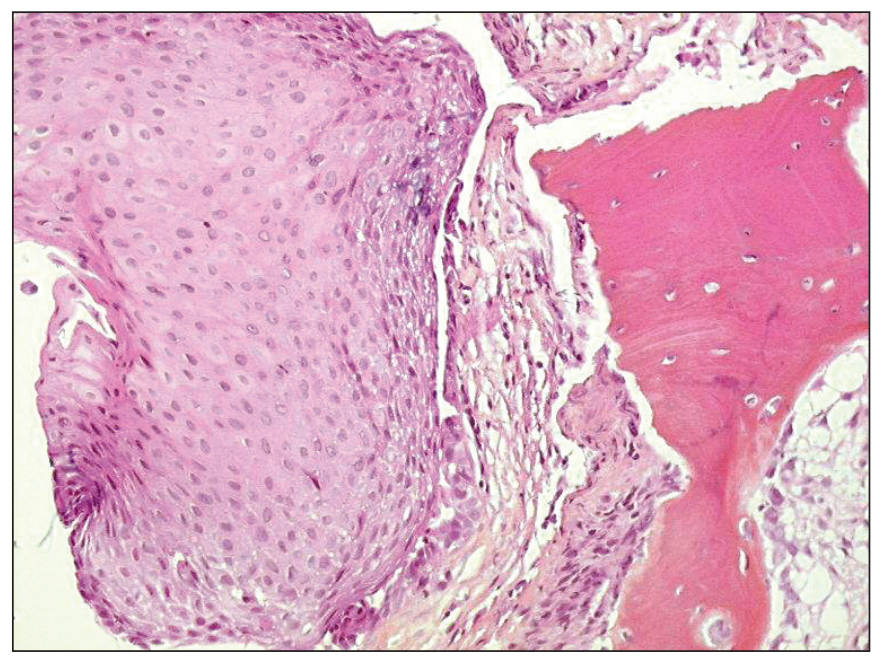

Figure 3: Bone infiltration by well differentiated squamous cell carcinoma. (H\&E Saffron; $\mathrm{x} 40$ ). 


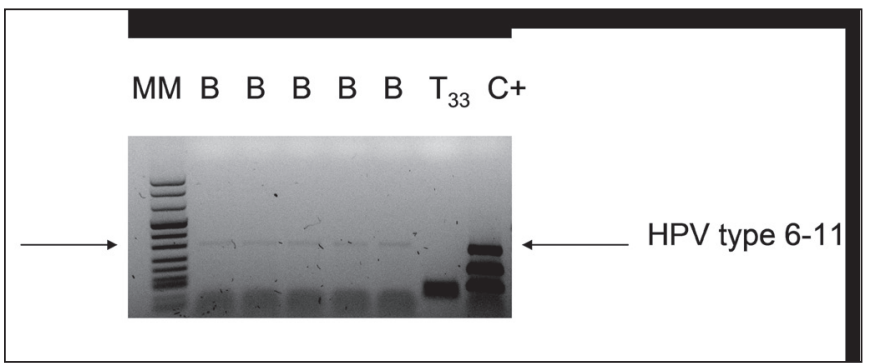

Figure 4: HPH 6/11 load.

well differentiated squamous cell carcinoma was diagnosed (Figure 3). A few weeks after the diagnosis, the patient condition continued to deteriorate and he died of multiples brain metastasis.

To extract total DNA, 4 sections of $10 \mu \mathrm{m}$ were cut from a formalin-fixed tissue block using a commercially available kit (QIA amp DNA mini kit, Qiagen, Valencia, CA). Samples were screened for HPV specific types 16, 18, 33, 45, 6 and 11 DNA and consensus HPV DNA (HPV $\mathrm{X}$ ) using GP5+/GP6+primers in five independent PCR. PCR amplification was performed in a $50 \mu \mathrm{L}$ volume and included $5 \mathrm{mM} \mathrm{MgCl} 2,0.2$ mole of dNTP, $1.25 \mathrm{U}$ Taq Gold DNA polymerase (Applied Biosystems, Foster City, CA, USA) and $1 \mu \mathrm{mol} / \mathrm{L}$ of each HPV type $3^{\prime}$ and 5 ' primers. The amplification ramp included $1 \mathrm{~min}$ at $94^{\circ} \mathrm{C}, 1 \mathrm{~min}$ at $55^{\circ} \mathrm{C}$ and $1 \mathrm{~min}$ at $72^{\circ} \mathrm{C}$ for 30 cycles, except consensus PCR where annealing temperature was $42^{\circ} \mathrm{C}$ for 40 cycles. PCR products were visualized on $0.5 \%$ agarose, $2 \%$ Nusieve gel stained with ethydium bromide. Positive control-plasmids and two independent negative controls were amplified in each run. All samples were tested for DNA integrity by PCR using primers for the human GAPDH gene (9). The presence of HPV 6/11 was demonstrated by five independent PCR analysis, on formalin-fixed paraffin-embedded tumor tissue from the bone metastatic lesion. The viral load was low, but HPV 6/11 HPV DNA was constantly found in all samplings, attesting the infection of the tumor (Figure 4). No material from papillomas was available in our laboratory, as the initial biopsy was performed in Guyana.

\section{DISCUSSION}

Juvenile recurrent respiratory papillomatosis (JRRP) remains a mysterious disease and is very difficult to manage. The median age of JRRP is 2 years, with a range of 2 months to 19 years. Eighty three percent of cases are diagnosed before 4 years of age (4). In this case, JRRP was diagnosed in the first 4 months of life.

The course of the disease is unpredictable. Papillomas may regress spontaneously. An aggressive course may occur when papillomas spread to the distal airways and to the lungs, probably protracted by iterative surgical interventions performed to avoid airway obstruction. A systematic review of the literature analyzed 11 publications on 161 cases of lung involvement in JRRP. The pooled data showed the incidence of lung involvement in JRRP at 3.3\% (from a cohort studies) and the incidence of malignant transformation at $16 \%$. The median interval between the diagnosis of JRRP and that of lung involvement is 8 years (range $<1-45$ years) (4).

Malignant transformation may occur, either at the laryngeal, bronchial or pulmonary level. The median interval between the diagnosis of JRRP and that of cancer is 19 years (12 years in this case). The youngest child reported to die of lung cancer was 6 years old and 31\% of the reported cases are diagnosed before the age of 18 years. The strongest risk factor for JRRP is a history of genital condyloma transmitted from the mother during delivery. HPV is the etiologic agent of respiratory papillomatosis. The virus is a $55 \mathrm{~nm}$ nonenveloped, icosahedron containing an $8 \mathrm{~kb}$ circular, covalently closed, double-strand genome. The genome consists of three regions: the long control region (LCR), which contains transcription regulatory sequences, the early and the late regions which are related to the phase of infection in which they are expressed (10). Gabott et al. evaluated HPV type and viral mutation occurring during the course of juvenile-onset recurrent respiratory papillomatosis in 199 papillomas excised from 47 children. Forty four children had HPV-induced papillomas, with type 11 accounting for 55\%, type 6 for $43 \%$ and both type 6 and 11 for $2 \%$ (11).

Despite the epidemiological classification of type 6 and 11 HPV as low risk HPVs, it has been reported in the literature that children with lesions containing HPV 11 have a more aggressive course than patients with HPV 6-associated lesions. HPV11 is associated with squamous cell carcinoma although HPV11 is uncommonly associated with the development of invasive carcinoma at other sites (12). Patients affected by HPV11 papillomatosis as in our case are younger, with a longer period of disease activity, require more surgical procedures and are less likely to go into remission than HPV 6-infected patients. These data suggest that HPV 11 may play a significant role in carcinogenesis in the larynx and respiratory tract, particularly in patients with JRRP. In summary, JRRP aggressiveness is in relation with two strong risk factors: the age at diagnosis of JRRP (laryngeal involvement) and HPV type.

Rady et al. demonstrated that the p53 genetic mutation was associated with integration of HPV-11 in histologically malignant lesions. This association may promote a progres- 
sive genetic instability that can lead to the development and clonal expansion of malignant lesions in JRRP (2). In our case, immunohistochemical analysis showed positive nuclear staining for $\mathrm{p} 53$.

Patients who receive radiation or cytotoxic drugs or those who subsequently smoke may be predisposed to the development of broncho-pulmonary carcinoma (8).

In this observation, HPV may be an important risk factor in the development of squamous cell carcinoma as the child did not receive radiation or cytotoxic drugs. In addition, HPV 6/11 DNA was detected by PCR-analysis in the metastatic tumor cells.

Clearly, to date, not enough data are available on the association of HPV type, the possible variation in HPV or the development of mutations and progression to cancer.

To conclude, many issues need to be improved in JRRP: the understanding of the mechanisms underlying the lung involvement as well as the risks associated with different HPV types and the risk of progression to cancer, strategies for early diagnosis of malignant transformation and adequate follow-up. Randomized control trials and prospective cohort studies are warranted (12). Significant vaccine research is being pursued for JRRP (13). In the future, the incidence of JRRP and squamous cell carcinoma may be reduced by the wild use of quadrivalent HPV vaccine for prevention of HPV 6/11.

\section{REFERENCES}

1. Wiatrak BJ, Wiatrak DW, Broker TR, Lewis L. Recurrent respiratory papillomatosis: A longitudinal study comparing severity associated with human papilloma viral types 6 and 11 and other risk factors in a large pediatric population. Laryngoscope. 2004;114:1-23.

2. Rady PL, Schnadig VJ, Weiss RL, Hughes TK, Tyring SK. Malignant transformation of recurrent respiratory papillomatosis associated with integrated human papillomavirus type $11 \mathrm{DNA}$ and mutation of P53. Laryngoscope. 1998;108:735-40.
3. Guillou L, Sahli R, Chaubert P, Monnier P, Cuttat JF, Costa J. Squamous cell carcinoma of the lung in a non smoking, non irradiated patient with juvenile laryngotracheal papillomatosis: Evidence of human papillomavirus-11 DNA in both carcinoma and papillomas. Am J Surg Pathol. 1991;15:891-8.

4. Gélinas JF, Manoukian J, Côté A. Lung involvement in juvenile onset recurrent respiratory papillomatosis: A systematic review of the literature. Int J Pediatr Otorhinolaryngol. 2008; 72:433-52.

5. Cook JR, Hill DA, Humphrey PA, Pfeifer JD, El-Mofty SK. Squamous cell carcinoma arising in recurrent respiratory papillomatosis with pulmonary involvement: Emerging common pattern of clinical features and human papillomavirus serotype association. Mod Pathol. 2000;13:914-8.

6. El Aatmani M, Steinmetz A, Debry C, Levêque D, Koffel JC, Beretz L. À propos d'un cas de papillomatose laryngée récidivante par injections intralésionnelles de cidovir (vistide ${ }^{\circledast}$ ). Journal de Pharmacie Clinique. 2002;21:287-90.

7. Simma B, Burger R, Uehlinger J, Ghelfi D, Hof E, Dangel P, Briner J, Fanconi S. Squamous-cell carcinoma arising in a non-irradiated child with recurrent respiratory papillomatosis. Eur J Pediatr. 1993;152:776-8.

8. Helmuth RA, Strate RW. Squamous cell carcinoma of the lung in a non-irradiated, non-smoking patient with juvenile laryngotracheal papillomatosis. Am J Surg Pathol. 1987;11:643-50.

9. De Cremoux P, De La Rochefordière A, Savignoni A, Kirova Y, Alran S, Fourchotte V, Plancher C, Thioux M, Salmon RJ, Cottu P, Mignot L, Sastre-Garau X. Different outcome of invasive cancer associated with high-risk HPV genotype versus intermediate-risk HPV genotype. Int J Cancer. 2009;124:778-82.

10. Reidy PM, Dedo HH, Rabah R, Field JB, Mathog RH, Gregoire $\mathrm{L}$, Lancaster WD. Integration of human papillomavirus type 11 in recurrent respiratory papilloma-associated cancer. Laryngoscope. 2004;114:1906-9.

11. Gabbott M, Cossart YE, Kan A, Konopka M, Chan R, Rose BR. Human papillomavirus and host variables and predictors of clinical course in patients with juvenile-onset recurrent respiratory papillomatosis. J Clin Microbiol. 1997;3098-103.

12. Bergler WF, Gotte K. Current advances in the basic research and clinical management of juvenile-onset recurrent respiratory papillomatosis. Eur Arch Otorhinolaryngol. 2000;257:263-9.

13. Wiatrak BJ. Overview of recurrent respiratory papillomatosis. Curr Opin Otolaryngol Head Neck Surg. 2003;11:433-41. 